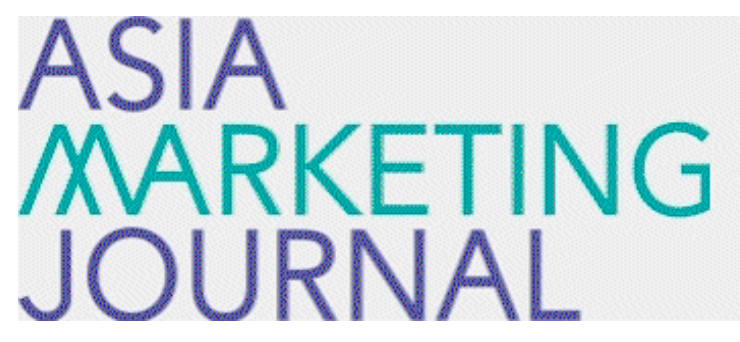

ASIA MARKETING JOURNAL

Volume 17 | Issue 4

Article 1

$1-31-2016$

\title{
The Past, Present, and Future of Marketing Research in Asia
}

Jaihak Chung

Follow this and additional works at: https://amj.kma.re.kr/journal

Part of the Marketing Commons

\section{Recommended Citation}

Chung, Jaihak (2016) "The Past, Present, and Future of Marketing Research in Asia," Asia Marketing Journal: Vol. 17 : Iss. 4 , Article 1.

Available at: https://doi.org/10.15830/amj.2016.17.4.1

This Article is brought to you for free and open access by Asia Marketing Journal. It has been accepted for inclusion in Asia Marketing Journal by an authorized editor of Asia Marketing Journal. 


\section{The Past, Present, and Future of Marketing Research in Asia}

Jaihak Chung*

The lack of international research networks in Asia has been a major barrier in bridging scattered Asian academic societies. As a result, most researchers in Asia are not familiar with which journals they can access for their research, nor where they can submit their valuable research manuscripts. Asian Marketing Journal (AMJ) and the International Conference of Asian Marketing Associations (ICAMA), both of which are managed by Asian scholars for Asian scholars, are expected to take on such roles to make a significant contribution to Asian academic societies by encouraging them to study and share research topics that are more relevant and helpful to Asian market studies that come from an Asian researcher's perspective. This study aims to acknowledge and explain the successful settlement of the International Conference of Asian Marketing Associations (ICAMA) and its representative journal, Asia Marketing Journal (AMJ), by discussing how ICAMA and AMJ were created, why they are necessary to Asian researchers, and what goals they hope to achieve. Another, arguably more important objective of this study is to provide Asian researchers with information on what topics Asian academia has been researching since 2000, and guide researchers as to which journals in Asian academia can publish their marketing research papers.

Key words: Marketing Journal, Research in Asia, Research Trends in Asia, International Conference

* Jaihak Chung (jaihak@sogang.ac.kr) is Professor of Marketing at the School of Business Administration, Sogang University, Seoul, Korea, and the chief-in editor of Asia Marketing Journal. We thank all the participants of 2015 ICAMA in Tokyo. We also appreciate Michel Phan (EMlyon University, France), Kawakami Tomoko (Waseda University, Japan), Alisara Charinsarn (Thammassat University, Thailand), Tat Keh(Monash University, Austrailia), Anirban Mukherjee (Singapore Management University, Singapore), Luping Sun(Central University of Finance and Economics, China), Wang Ping (Zhejiang Normal University, China), and Vera A Rebiazina (National Research University Higher School of Economics, Russia) for their valuable advices and information. Finally we appreciate Hyungdong Park, Mintaek Hong, Jungwhan Seo, and Eunsil Lee for their significant help for data collection, and Ian Sutherland for his excellent advices. 


\section{Introduction}

As most markets in the world continue to become more and more globalized at an unprecedented pace, the need is also increasing for marketing researchers to share their research interests and knowledge with researchers in other countries. In this way, researchers are able to paint a better picture of global markets and conduct more useful research for industry practitioners working in the context of these global markets. The most popular and effective veins for academia's intellectual interactions are academic conferences and academic journals. American academics have been active on this scene by sharing their interests and information from their own perspectives via a variety of well-known conferences, such as The Association for Consumer Research (ACR) conference (www. acrweb.org/acr) and Marketing Science Conference (INFORMS Society for Marketing Science, https: //www.informs.org), and also with the help of top tier journals such as the Journal of Marketing (JM), Journal of Market Research (JMR), Journal of Consumer Research (JCR), Marketing Science (MS) and so on. European academics can also share their research interests and collaborate with other researchers in other countries via their own network hubs, such as through a variety of EMAC (the European Marketing Academy) regional and annual conferences (www.emaconline.org) and International Marketing Trends
Conference (www.marketing-trends-congress.com), as well as through journals including International Journal of Research in Marketing (IJRM), European Journal of Marketing (EJM), and Journal of Marketing Trends (JMT).

While such conferences and journals are widely open to researchers not only from Western countries but also in Asia, there still tends to be a bias toward issues that are of interest to Western perspectives. International journals and conferences organized by Western scholars are inclined to foster research that emphasize topics of interest to Western researchers' perspectives, since most of conference attendants and staff are academics working in Western countries. Worldclass Western journals are also not free from this type of bias, because not all, but an majority of the editors and editorial board members of most Western journals work in Western regions, mainly the USA and Europe.

In contrast, there have been few international conferences and international journals mainly organized by Asian academic organizations. For instance, though many international conferences for marketing researchers are held in Asia, 78\% of them in 2015 were mainly administrated by non-Asian academic groups and firms according to a portal site of international conferences, Conference Alert (http://www.conferencealerts. $\mathrm{com} /$ ). Interestingly, Western academic societies have issued at least two marketing journals and four management journals focusing on Asian markets, as Asian markets have continued to 
become one of the fastest growing markets in the world over the past decade; Asia Pacific Business Review Asia Pacific, Journal of Marketing and Logistics, Asian Business and Management, Asian Journal of Marketing, Journal of Asia Pacific Business, and Journal of Asian Business.

Therefore, research topics that are of utmost importance for industry practitioners working in Asian markets, have been understudied in the marketing literature. The lack of international conferences and journals originazed by Asian academics has been a major barrier in bridging scattered Asian academic societies. As a result, most researchers in Asia are not familiar with which journals they can access for their research, nor where they can submit their valuable research manuscripts. Asian academic societies need to unite to establish an international research network for Asian researchers, in order to boost the esteem of Asian research publications. Given that there are not many research venues for Asian researchers to share their knowledge and research information across countries, Asian Marketing Journal (AMJ) and the International Conference of Asian Marketing Associations (ICAMA), both of which are managed by Asian scholars for Asian scholars, are expected to take on such roles and make a significant contribution to Asian academic societies by encouraging them to study and share research topics that are more relevant and helpful to Asian market studies that come from an Asian researcher's perspective.
This special issue commemorates the success of the $2^{\text {nd }}$ ICAMA (International Conference of Asian Marketing Associations) held in Tokyo during 2015, as well as the 5th anniversary of the successful repositioning of the Asia Marketing Journal (AMJ) as an international journal for Asian scholars, by assembling research papers presented at the 2015 ICAMA. Therefore, this study aims to acknowledge the successful settlement of the International Conference of Asian Marketing Associations (ICAMA) and its representative journal, Asia Marketing Journal (AMJ), by discussing how ICAMA and AMJ were created, why they are necessary to Asian researchers, and what goals they hope to achieve. Another, arguably more important objective of this study is to provide Asian researchers with information on what topics Asian academia has been researching since 2000, and guide researchers as to which journals in Asian academia can publish their marketing research papers. Lastly, we aim to recommend topics relevant for Asian markets to Asian researchers and deliberate the desirable roles of marketing journals in Asia.

\section{The Birth of ICAMA (International Conference of Asian Marketing Associations) and AMJ (Asia Journal Marketing)}

In 2012, the Korean Marketing Association 
(KMA) initiated a meeting to discuss ideas on how to share works of research and how to collaborate with the two major marketing associations in China and Japan, known respectively as Chinese Academy of Marketing Science (CAMS) and Japan Society of Marketing and Distribution (JSMD). At the meeting during the 2012 Marketing Conference held by The Council of Chinese Academy of Marketing Science in Dalien, China, the presidents of the three associations, Changjo Yoo (KMA), Zhao Ping (CAMS), and Kyoichi Ikeo (JSMD) agreed to organize an annual international joint conference, called the International Conference of Asian Marketing Associations (ICAMA), for the development of a international research hub for Asian researchers. According to the agreement, the three marketing associations host the annual ICAMA event alternatively between them from 2014. As the first step, the Korean Marketing Association hosted the $1^{\text {st }}$ ICAMA with the help of Chinese Academy of Marketing Science (CAMS) and Japan Society of Marketing and Distribution (JSMD) in Seoul, on March 13-15, 2014. The $1^{\text {st }}$ ICAMA, under the theme of "Consumption Trends in Asian Markets", offered four different types of sessions: global, Korean, Japanese, and Chinese sessions, consisting of 24 sessions, and attracting 323 attendants from not only Korea, China, and Japan, but also from many other Asian countries (in total 16 countries from 62 universities and 11 companies). In 2015, the $2^{\text {nd }}$ ICAMA, with the theme of "Emerging Trends in Asian Markets", was also successful, and held in Tokyo, Japan, hosted by the Japan Society of Marketing and Distribution (JSMD). The 3rd ICAMA is expected to be held in Beijing, China, by Chinese Academy of Marketing Science (CAMS) in 2016. ICAMA (International Conference of Asian Marketing Associations) has been designed to be literally "the first international marketing conference of the Asian, by the Asian, for the Asian marketing researchers." For the last five years, these three associations have been arduously working together to provide a major research platform where all the academic researchers and industry practitioners interested in Asian markets can share their knowledge and information on "what is happening in Asian markets." This conference is the outcome of the five years of collaboration among the three marketing associations.

Asia Marketing Journal, previously titled Korea Marketing Review, was founded in 1998 as a domestic journal for Korean researchers by the KMA (Korean Marketing Association). Since then, AMJ, accredited by KCI (Korea Citation Index), had been a major platform for the dissemination of recent research knowledge and information among domestic scholars and industry practitioners for fourteen years until 2012. In 2012, the Korean Marketing Association (KMA), in need of a global research network, decided to reposition one of their two major journals, AMJ, as an international journal for 
Asian scholars and researchers who are interested in marketing research in Asian markets. One of the main driving factors for the rebirth of AMJ was the necessity of globalizing their research networks, not only for Korean, but also for all other Asian researchers. Another motivation was the necessity of distributing the research outcomes, presented in the conference organized by Asian marketing associations, to all the researchers in Asia as the representative journal of the conference.

In 2012, the first editor-in-chief of AMJ, Sangyong Kim, changed the title of the journal to Asia Marketing Journal (ISSN 1598-7868), and successfully launched the journal by publishing research papers written in English only, rebuilding the editorial board with globally $\mathrm{rec}^{-}$ ognized scholars from the USA, China, Japan, and Singapore, and revising the journal's format, review process, and website, in order to match the global standard for international journals. Asia Marketing Journal publishes research papers, insightful research notes and case studies quarterly, in English during April, July, October and January. Due to the chief-in editor's effort, AMJ has been successfully repositioned as an esteemed international journal.

Since then, AMJ has been fast becoming a leading outlet for cutting edge research about Asian markets. The journal embraces not only the major or popular topics, such as brand, advertising, and so on, but also Asian market-related topics, including global or localized mar- keting strategies for companies in Asian markets, the cross-cultural study of Asian consumers, and successful cases of global or local companies in Asia.

\section{Current Status of Academic Journals in Asia}

One of the main purposes of this study is to provide information on other major journals that publish academic research on marketing issues in Asia. However, it is not always clear how to define the scope of study for journals, because a variety of journals are managed, not by academic, but by industry organizations, which publish academic manuscripts on marketing topics. This study concentrates on only those journals publishing academic research papers, notes, and cases on marketing topics that are related to Asian markets or managed by Asian academic or public organizations. The journals relevant for our study were chosen as follows: Firstly, we asked eight marketing scholars in seven Asian countries (Australia, China, Japan, Thailand, Singapore, South Korea, Russia) to provide information on any academic journals that most marketing scholars in their respective countries consider as major academic journals for marketing research (henceforth, we call marketing journals), and any other journals that publish research papers on marketing topics (we 
〈Table 1〉 Asian Marketing Journal List

\begin{tabular}{|c|c|c|c|c|}
\hline Nationality & Publisher & Title & Issue & ISSN \\
\hline Australia & Emerald Group Publishing Limited & Asia Pacific Journal of Marketing and Logistics & 5 & $1355-5855$ \\
\hline Australia & Monash University & Asia-Australia Marketing Journal & 5 & $1320-1646$ \\
\hline Australia & $\begin{array}{l}\text { Australian and New Zealand } \\
\text { Marketing Academy }\end{array}$ & Australasian Marketing Journal & 1 & $1441-3582$ \\
\hline China & $\begin{array}{l}\text { Tsinghua University and Peking } \\
\text { University }\end{array}$ & Journal of Marketing Science & 3 & 2187-8315 \\
\hline India & Indian Research Journals.com & $\begin{array}{l}\text { Asia Pacific Journal of Marketing \& } \\
\text { Management Review }\end{array}$ & 12 & $2319-2836$ \\
\hline India & Asia-Pacific Institute of Management & Asia-Pacific Marketing Review & 2 & $2277-2057$ \\
\hline India & Asian Research Consortium & Asian Journal of Research in Marketing & 6 & $2277-6621$ \\
\hline India & ELK Education Consultants & $\begin{array}{l}\text { ELK Asia Pacific Journal of Marketing and } \\
\text { Retail Management }\end{array}$ & 4 & 0976-7193 \\
\hline India & $\begin{array}{l}\text { J.A. Alpha Business Research and } \\
\text { Publishers Pvt. Ltd. }\end{array}$ & $\begin{array}{l}\text { Global Journal of Emerging Trends in e-business, } \\
\text { Marketing and Consumer Psychology }\end{array}$ & 2 & $2311-3170$ \\
\hline India & $\begin{array}{l}\text { Associated Management Consultants } \\
\text { Private Limited }\end{array}$ & Indian Journal of Marketing & 12 & 0973-8703 \\
\hline India & Publishing India Group & $\begin{array}{l}\text { International Journal of Marketing and Business } \\
\text { Communication }\end{array}$ & 4 & $2277-484 X$ \\
\hline India & Publishing India Group & Practices and Research in Marketing & 2 & 2230-844X \\
\hline Indonesia & Universitas Indonesia & ASEAN Marketing Journal & 2 & 2085-5044 \\
\hline Indonesia & University of Diponegoro & Indonesian Journal of Marketing Science & 2 & $1412-8527$ \\
\hline Indonesia & Petra Christian University & Marketing Management Journal & 2 & 1907-235X \\
\hline Japan & $\begin{array}{l}\text { Japan Association for Consumer } \\
\text { Studies }\end{array}$ & Advances in Consumer Studies & 2 & $1883-9576$ \\
\hline Japan & Japan Marketing Academy & Japan Marketing Academy Marketing Journal & 4 & - \\
\hline Japan & Japan Institute of Marketing Science & JIMS Marketing Science & 1 & $2187-8315$ \\
\hline Japan & $\begin{array}{l}\text { Japan Society of Marketing and } \\
\text { Distribution }\end{array}$ & Journal of Marketing and Distribution & 4 & $1345-9015$ \\
\hline Korea & Korean Marketing Association & Asia Marketing Journal & 4 & $1598-7868$ \\
\hline Korea & Korea Distribution Association & Journal of Channel and Retailing & 2 & $1226-9263$ \\
\hline Korea & Korean Society of Consumer Studies & Journal of Consumer Studies & 4 & $1226-282 X$ \\
\hline Korea & Korean Scholars of Marketing Science & Journal of Global Fashion Marketing & 4 & 2093-2685 \\
\hline Korea & Korean Scholars of Marketing Science & Journal of Global Scholars of Marketing Science & 1 & $1229-7119$ \\
\hline Korea & $\begin{array}{l}\text { Korean Strategic Marketing } \\
\text { Association }\end{array}$ & Journal of Marketing Studies & 2 & $1229-3180$ \\
\hline Korea & Korean Marketing Association & Korea Marketing Review & 4 & $1229-456 \mathrm{x}$ \\
\hline Korea & Service Marketing Association & Service marketing Journal & 2 & 2005-3207 \\
\hline Russia & Grebennikov Publishing House & Marketing and market research & 6 & - \\
\hline UK & $\begin{array}{l}\text { MCB University Press/Emerald Group } \\
\text { Publishing Limited }\end{array}$ & Asia Pacific Journal of Marketing and Logistics & 4 & $1355-5855$ \\
\hline USA & Academic Journals Inc. & Asian Journal of Marketing & 2 & 1819-1924 \\
\hline USA & The Association for Asian Studies Inc. & Journal of Asian Business & 4 & $1068-0055$ \\
\hline
\end{tabular}


call management journals). Secondly, we found journals that were referenced in any webpages containing keywords ("journal" "marketing" , “Asia”, or each country's name) via a search engine, Google. By examining all such webpages, we excluded non-academic journals, journals that are not listed in major international journal indexes, such as SCOPUS, H-index, and the corresponding countries' national journal indexes in each Asian country, and journals that do not issue their publications regularly. Lastly, 31 marketing journals that publish only marketing research and 31 management journals that accept research on marketing topics were collected for this study. The list of marketing journals in Asia are given in 〈Table 1〉. As shown in the marketing journal distribution in Asia below, South Korea and India own the largest number of marketing journals. It is somewhat surprising that China and Russia have only one journal each, focusing on marketing research. While most of ASEAN countries do not have marketing journals, non-Asian countries such as the USA and the UK have two and one marketing journals targeting research about Asian markets, respectively.

Management journals publishing research on marketing topics are listed as below in $\langle$ Table 2$\rangle$.

$\langle$ Figure 2〉 shows the distribution of management journals in Asia. China, South Korea, and Malaysia each have six management journals. Thailand owns eight management journals, while not owning any marketing journal.

〈Figure 3〉 shows the number of journals established over the last 55 years since 1960. The graph shows clearly that not many journals were available before 1990. The 1990's seems to be the take-off time period from the perspective of Asian marketing academia, since most journals were established after 1990. In addition, it is also

〈Figure 1〉

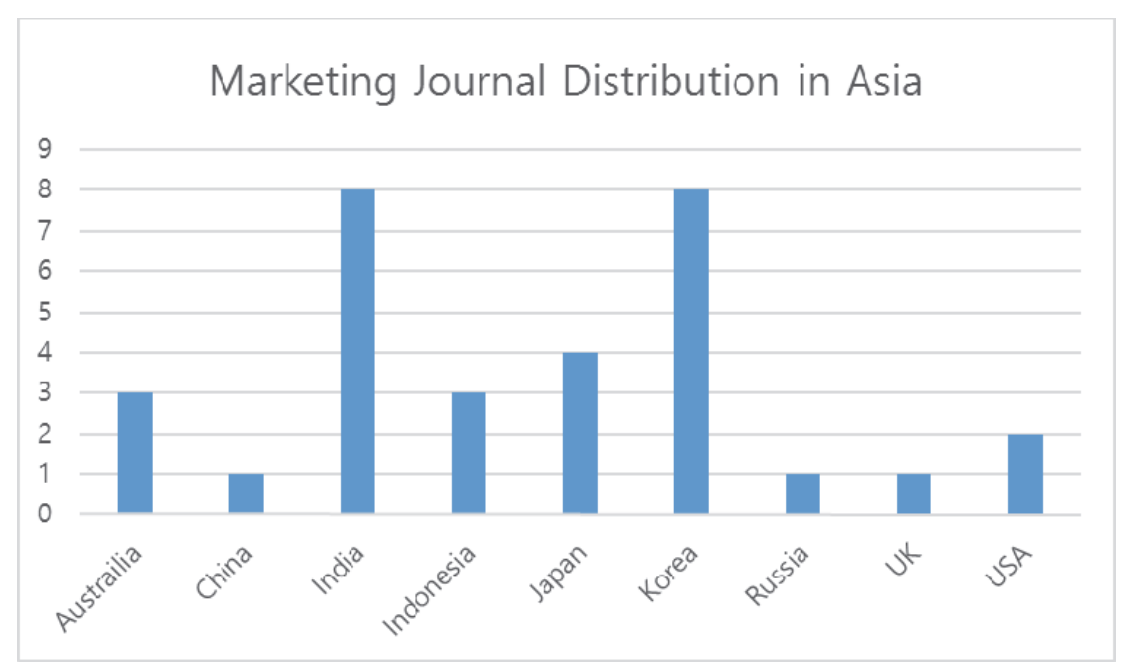

The Past, Present, and Future of Marketing Research in Asia 7 
〈Table 2〉 Management Journal List

\begin{tabular}{|c|c|c|c|c|}
\hline Nationality & Publisher & Title & Issue & ISSN \\
\hline Australia & $\begin{array}{l}\text { Asian Journal of Management } \\
\text { Sciences }\end{array}$ & Asian Journal of Management Sciences & 12 & $2348-0351$ \\
\hline Australia & IGI Global & $\begin{array}{l}\text { International Journal of Asian Business and } \\
\text { Information Management }\end{array}$ & 4 & $1947-9638$ \\
\hline Australia & $\begin{array}{l}\text { Mac Scholar : Marketing in Asia } \\
\text { Group }\end{array}$ & The Asian Journal of Business Research & 6 & $1178-8933$ \\
\hline Australia & Zia World Press & World Journal of Management & 2 & 1836-070X \\
\hline China & China Soft Science & China Soft Science Magazine & 6 & 1001-8409 \\
\hline China & $\begin{array}{l}\text { Shanghai University of Finance } \\
\text { and Economics }\end{array}$ & Foreign Economics \& Management & 12 & $1001-4950$ \\
\hline China & Harbin Institute of Technology & Journal of Management Science & 6 & - \\
\hline China & Tianjin University & Journal of Management Sciences in China & 12 & $1007-9087$ \\
\hline China & $\begin{array}{l}\text { China Development Research } \\
\text { Center }\end{array}$ & Management World & 5 & $1002-5502$ \\
\hline China & Science Research Management & Research management & 12 & $1000-2995$ \\
\hline India & $\begin{array}{l}\text { International Management } \\
\text { Institute/Elsevier }\end{array}$ & Global Business Review & 2 & 0972-1509 \\
\hline India & $\begin{array}{l}\text { Shrimad Rajchandra Institute of } \\
\text { Management and Computer } \\
\text { Application }\end{array}$ & Global Journal of Research in Management & 2 & 2319-8915 \\
\hline India & Publishing India Group & Journal of Entrepreneurship \& Management & 3 & $2277-6850$ \\
\hline India & $\begin{array}{l}\text { XLRI School of Business and } \\
\text { Human Resources }\end{array}$ & Management and Labour Studies & 4 & $0258-042 X$ \\
\hline Indonesia & Gadjah Mada University & $\begin{array}{l}\text { Gadjah Mada International Journal of Business } \\
\text { (Gama IJB) }\end{array}$ & 3 & $1411-1128$ \\
\hline Indonesia & Bandung Technological Institute & The Indonesian Journal of Business Administration & 3 & $2252-3464$ \\
\hline Japan & $\begin{array}{l}\text { Japan Society of Business } \\
\text { Administration }\end{array}$ & journal of business management & 2 & $1691-5348$ \\
\hline Japan & $\begin{array}{l}\text { Japan Industrial Management } \\
\text { Association }\end{array}$ & $\begin{array}{l}\text { Journal of Japan Industrial Management } \\
\text { Association }\end{array}$ & 2 & 0386-4812 \\
\hline Korea & $\begin{array}{l}\text { Korean Academy of International } \\
\text { Business }\end{array}$ & International Business Studies & 1 & $1598-2718$ \\
\hline Korea & $\begin{array}{l}\text { Korean Academy of International } \\
\text { Business }\end{array}$ & International Business Studies & 1 & $1598-2718$ \\
\hline Korea & $\begin{array}{l}\text { Korea Research Academy of } \\
\text { Distribution and Management }\end{array}$ & $\begin{array}{l}\text { Korea Research Academy of Distribution and } \\
\text { Management Review }\end{array}$ & 1 & $1598-012 X$ \\
\hline Korea & $\begin{array}{l}\text { Korean Academy of Commodity } \\
\text { Science \& Technology }\end{array}$ & $\begin{array}{l}\text { Korean Academy Of Commodity Science \& } \\
\text { Technology }\end{array}$ & 6 & $1226-6132$ \\
\hline Korea & $\begin{array}{l}\text { East Asia Business Economics } \\
\text { Association }\end{array}$ & The East Asian Journal of Business Economics & 4 & $2288-4629$ \\
\hline
\end{tabular}


〈Table 2〉 Management Journal List (continue)

\begin{tabular}{|c|c|c|c|c|}
\hline Nationality & Publisher & Title & Issue & ISSN \\
\hline Korea & Korea Advertising Society & $\begin{array}{l}\text { The Journal of Advertising and Promotion } \\
\text { Research }\end{array}$ & 1 & $1225-0554$ \\
\hline Malaysia & $\begin{array}{l}\text { Penerbit Universiti Sains } \\
\text { Malaysia }\end{array}$ & Asian Academy of Management Journal & 2 & $1394-2603$ \\
\hline Malaysia & Macau Foundation & Euro Asia journal of management & 2 & 0872-8496 \\
\hline Malaysia & Indian Institute of Management & IIMB Management Review & 4 & 0970-3896 \\
\hline Malaysia & Universiti Malaysia Sarawak & International Journal of Business and Society & 2 & $1511-6670$ \\
\hline Malaysia & $\begin{array}{l}\text { Vilnius Gediminas Technical } \\
\text { University }\end{array}$ & Journal of Business Economics and Management & 2 & $1611-1699$ \\
\hline Malaysia & Universiti Utara Malays & Malaysian Management Journal & 1 & $0128-6226$ \\
\hline Phillippines & $\begin{array}{l}\text { Ateneo Graduate School of } \\
\text { Business }\end{array}$ & $\begin{array}{l}\text { AGSB Journal of Business Management and } \\
\text { Entrepreneurship }\end{array}$ & 1 & $1833-3850$ \\
\hline Phillippines & De la Salle University & DLSU Business and Economics Review & 2 & 0116-7111 \\
\hline Russia & Moscow State University & $\begin{array}{l}\text { Bulletin of Moscow University. 6. A series of } \\
\text { Economics }\end{array}$ & 6 & - \\
\hline Russia & Saint Petersburg State University & Russian Management Journal & 4 & $1729-7427$ \\
\hline Russia & $\begin{array}{l}\text { Vestnik of Saint Petersburg } \\
\text { University }\end{array}$ & $\begin{array}{l}\text { Vestnik of Saint Petersburg University } \\
\text { Management Series }\end{array}$ & 4 & $1605-7953$ \\
\hline Singapore & National University of Singapore & Asia Pacific Journal of Management & 2 & $0217-4561$ \\
\hline Singapore & $\begin{array}{l}\text { Singapore Institute of } \\
\text { Management }\end{array}$ & Singapore Management Review & 2 & $0129-5977$ \\
\hline Taiwan & National Cheng Kung University & Asia Pacific management review & 4 & $1029-3132$ \\
\hline Taiwan & Tamkang University & $\begin{array}{l}\text { International Journal of Information and } \\
\text { Management Sciences }\end{array}$ & 4 & $1017-1819$ \\
\hline Taiwan & National Taiwan University & NTU Management Review & 3 & $1018-1601$ \\
\hline Taiwan & NCTU Press & Quality Technology and Quantitative Management & 4 & $1684-3703$ \\
\hline Thailand & Assumption University & ABAC Journal & 2 & 0858-0855 \\
\hline Thailand & Stamford International University & ASEAN Journal of Management \& Innovation & 2 & $2351-0110$ \\
\hline Thailand & Assumption University & AU Journal of Management & 2 & $1686-0039$ \\
\hline Thailand & Assumption University & AU-GSB e-Journal & 2 & $1906-3296$ \\
\hline Thailand & Chulalongkorn University & Chulalongkorn Business Review & 2 & $0125-6564$ \\
\hline Thailand & Thammassat University & Journal of Business Administration & 6 & $0125-233 X$ \\
\hline Thailand & $\begin{array}{l}\text { University of Sukhothai Kingdom } \\
\text { Thammatirat }\end{array}$ & Modern Management Journal & 2 & $1686-7319$ \\
\hline Thailand & Chulalongkorn University & Sasin Journal of Management & 1 & $0859-2659$ \\
\hline UK & Frank Cass & Asia Pacific business review & 4 & $1360-2381$ \\
\hline UK & Palgrave MacMillan & Asian Business and Management & 5 & $1472-4782$ \\
\hline USA & International Business Press & Journal of Asia Pacific Business & 4 & $1059-9231$ \\
\hline
\end{tabular}


〈Figure 2〉

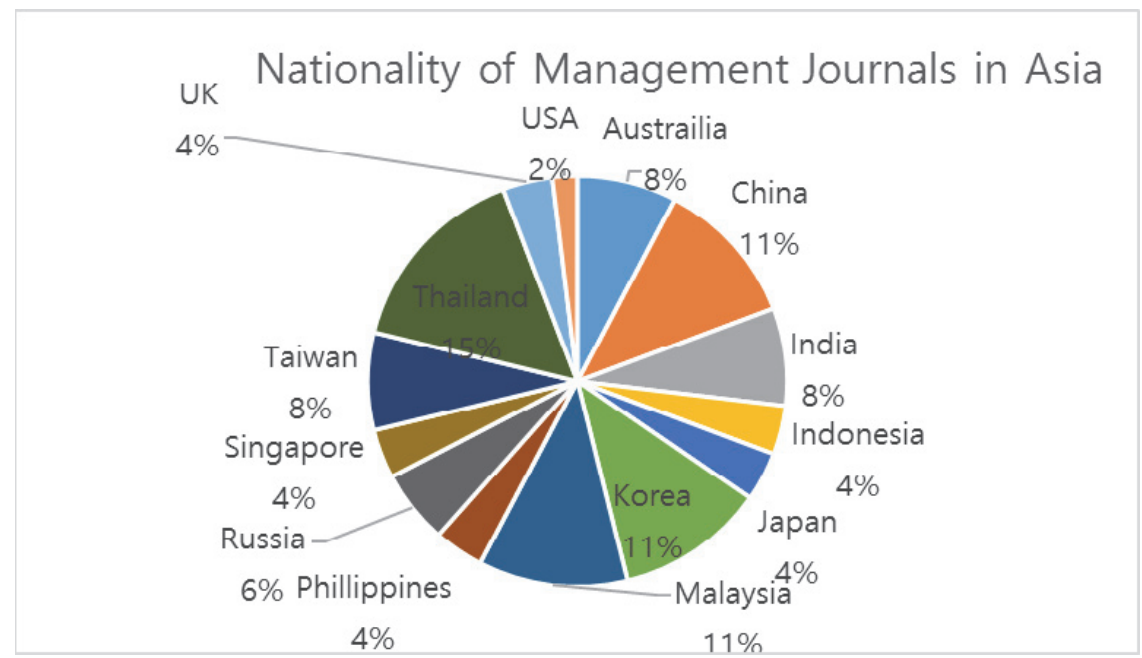

〈Figure 3〉

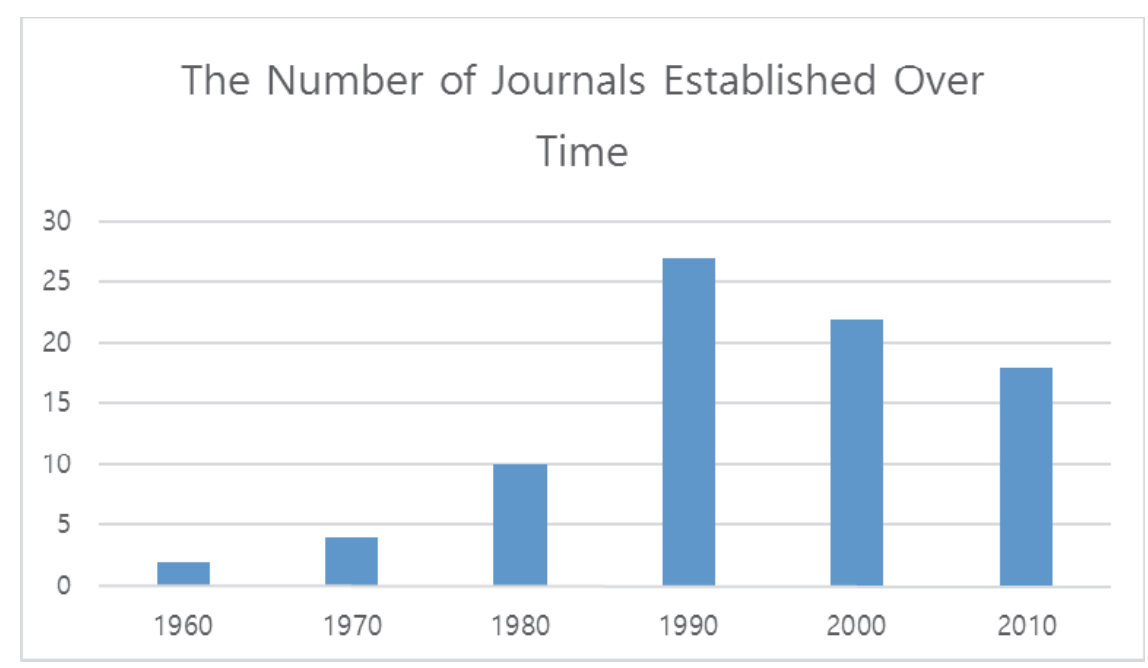

noteworthy that $84 \%$ of international journals in Asian countries except the countries that use English as the first language such as Australia, Newzealand, Phillippines, and Singapore, have been established since 1990. It implies that Asian researchers started to pay attention to intellectual interaction with other countries from 1990.

\section{Research trends in Asia}

In order to share information on what researchers have studied in Asia, we collected the research publications of Asian researchers in major Asia universities. This study limits the 
research publications of Asian researchers to all the academic research papers and notes on marketing topics written by academic faculties in major Asian universities in each country, but not limit the research publications to those published by Asian journals but by any international or local journals. The research papers for our study published by Asian scholars since 2000 were collected as described below; Firstly, we selected maxium 10 management schools from each Asian country, which are ranked by university ranking studies such as QS Global 200 MBA Rankings Asia Pacific (http://www. topmba.com/mba-rankings/region/asia) in 2015 or Eduniversal Business School Rangking (http: //www.eduniversal-ranking.com), or which have been accredited by AACSB, EQUIS, or AMBA. in fourteen Asian countries (Australia, NewZealand, China, Hongkong,, Taiwan, Malayisia, Vietnam, Indonesia, Mongolia, Singapore, Japan, Thailand, South Korea, Russia). Secondly, information on published research papers of faculty members in those universities, including research paper titles, year, and journal titles were obtained from the websites of the corresponding business schools or the faculties' personal websites via google. In case that no English titles are available, the corresponding research titles in their local languages, were translated via google translation and then validated by native speakers. In total, information on 5,926 research papers written by 512 Asian researchers from 145 universities in 16 countries. Please refer to Appendix A for the lists of Asian Universities.

In order to analyze what type of research topics have been studied by Asian researchers, we, as the first step, counted the frequencies of any words contained in the title of each research paper. As the second step, all the marketing concept-related words were grouped into four categories of topics: words related to global strategy, methodology, 4Ps, and Consumer Behavior. Lastly, all the papers were categorized into those four types based on their research titles. Please note that research papers were categorized not exclusively into those types. 〈Figure 4〉 shows the number of research papers on the four topics over the last 15 years from 2000 to 2015 as shown below.

The trend graph shows clearly that researchers in most of Asian countries have preferred studies on 4Ps (Product, Price, Promotion, or Place). Especially, researchers in South Korea have researched topics on 4Ps even more than other topics. However, researchers in Hongkong have researched consumer behavior topics significantly more than $4 \mathrm{P}$ related topics. It is noteworthy that researchers in Australia and New Zealand have been much more interested in global strategy in Asian markets compared to researchers in other Asian countries.

Further, we categorized the research papers on $4 \mathrm{P}$ into product, promotion, price, channel, and brand. 〈Figure 5〉 shows the numbers of $4 \mathrm{P}-$ related research topics, as shown below, in order to provide information on what topics re- 
〈Figure 4〉

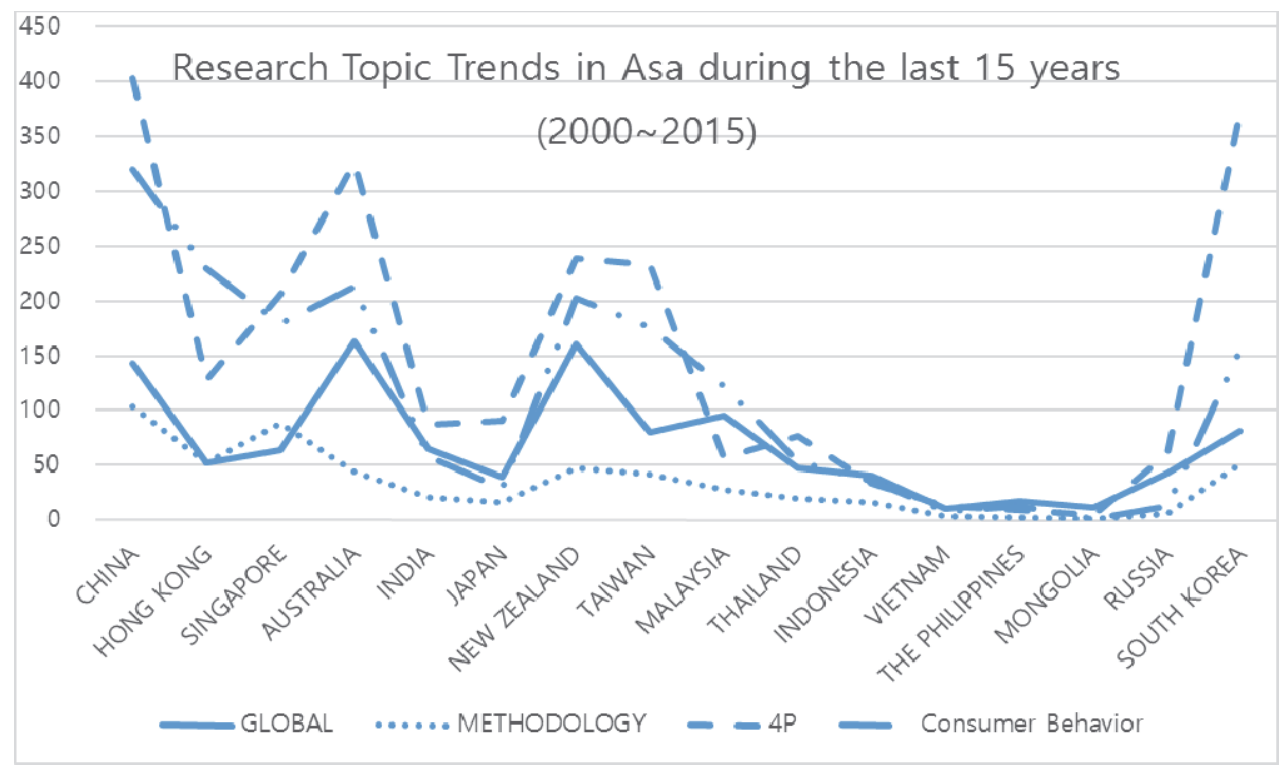

searchers in each country are more interested in within a country.

〈Figure 5〉 shows Asian researchers' preference heterogeneity across countries. Price is not a popular topic in most countries. Research on channel and brand is popular in China but, researchers in Hongkong have different preferences from in China. It is also interesting that researchers in Hongkong and Singapore prefer similar topics such as product and channel. It is also noteworthy that brand is the most popular research topic in many Asian countries. Research on product is more popular in relatively rich countries such as Singapore, Australia, and South Korea.

We categorized the research papers on consumer behavior into emotion, attitude, preference, choice decision, and satisfaction. 〈Figure
6) shows the numbers of those research topics as shown below.

$\langle$ Figure 6〉 shows that researchers in each country have significantly different research interests. Researchers in Hongkong, China, Australia, and New Zealand have published more papers on choice decision. Researchers in South Korea have been more interested in attitude, especially brand attitude. Consumer Satisfaction has been a popular research topic in China, Australia, Taiwan, and South Korea. It is noteworthy that consumer behavior has not been much studied in Japan. Researchers in Japan have been working on somewhat unique topics, such as industryoriented topics and cases.

In conclusion, this study shows heterogeneities in researchers' interests across Asian countries. 
$\langle$ Figure 5〉

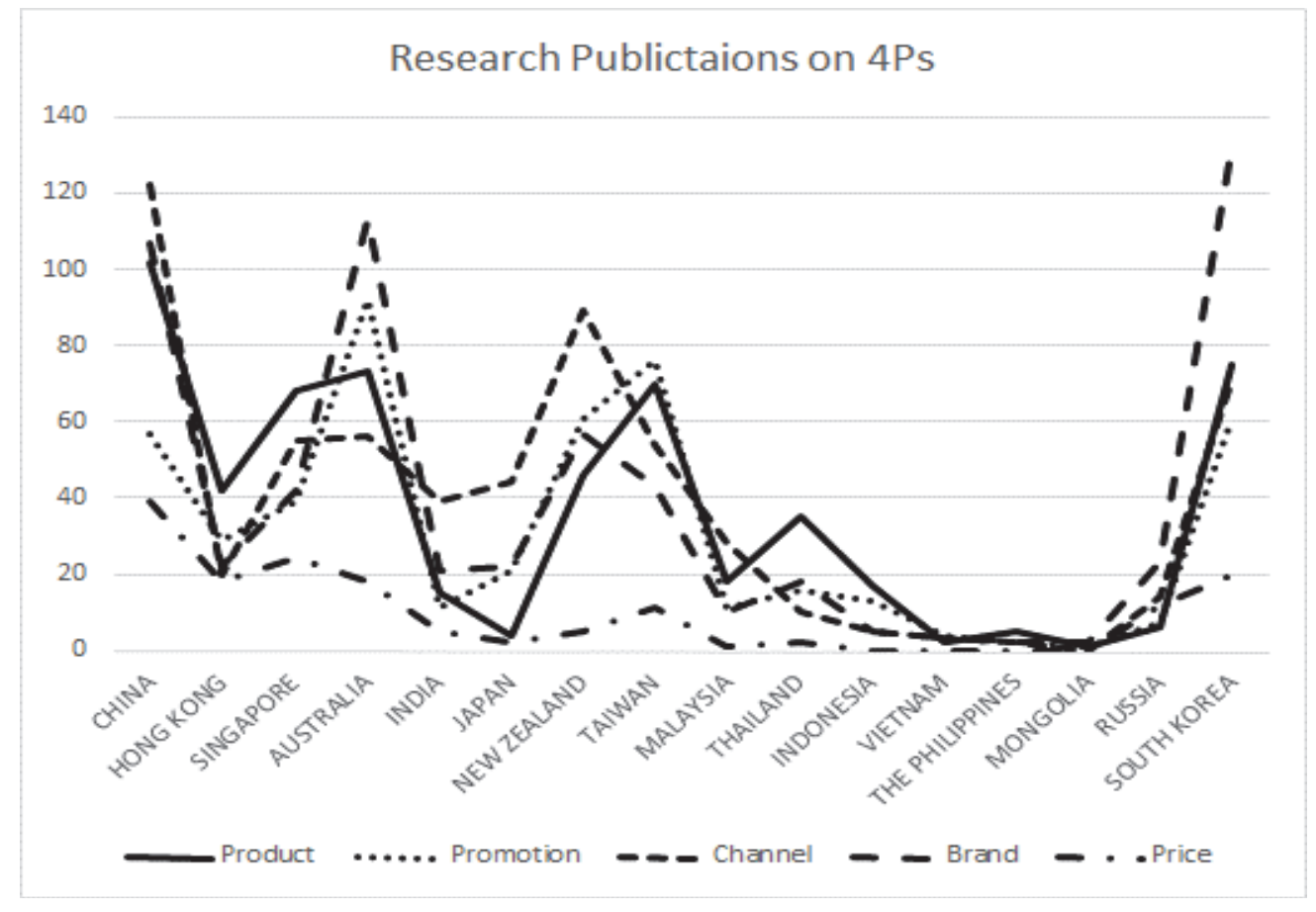

〈Figure 6〉

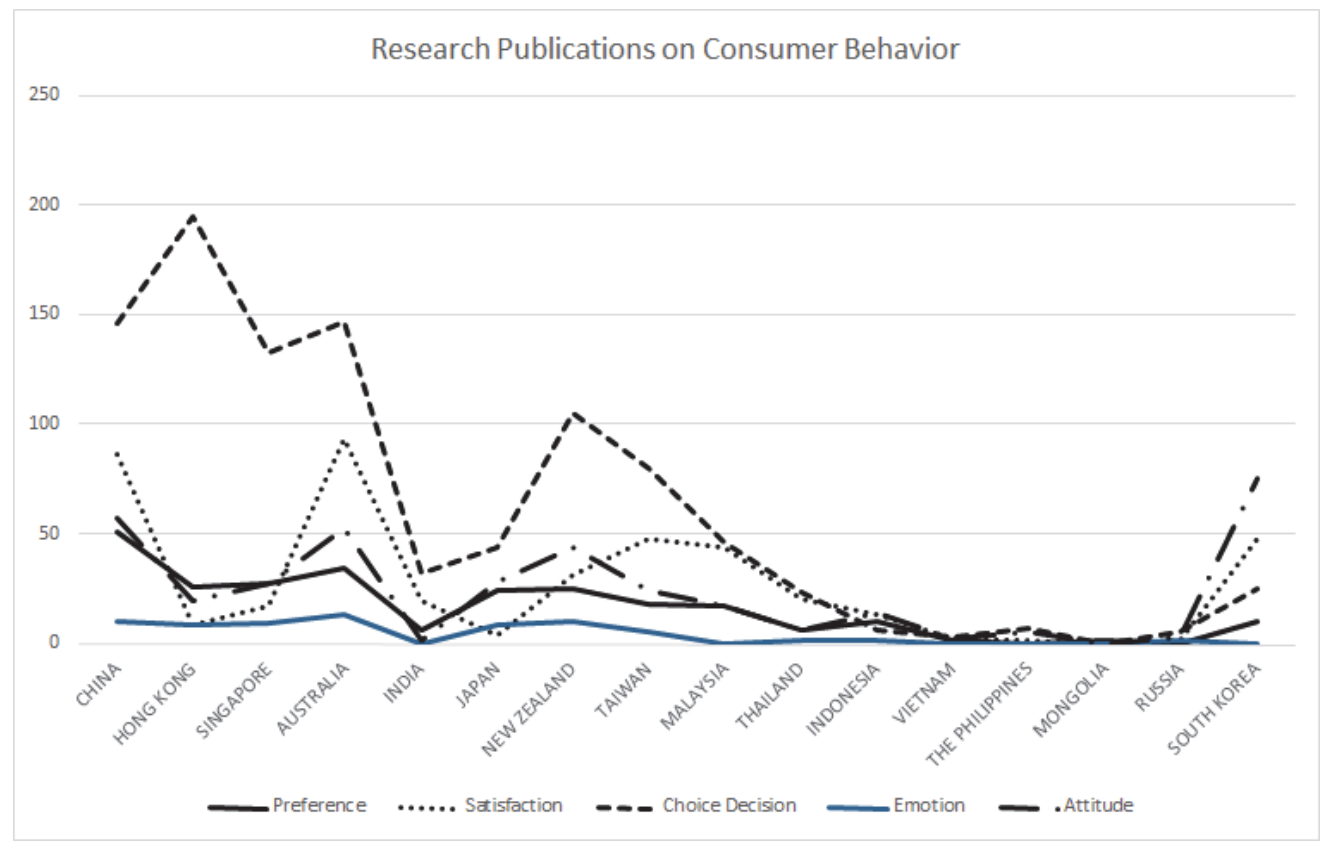

The Past, Present, and Future of Marketing Research in Asia 13 


\section{Conclusion}

We have addressed the necessity of Asian marketing journals and conferences for $\mathrm{re}^{-}$ searchers across Asian countries, and explained how ICAMA and AMJ were organized. We also provided information on Asian journals publishing marketing research on Asian markets and discussed the current status and trends of Asian journals. Lastly, we analyzed what topics have been usually studied by Asian scholars over the last fifteen years and discussed what research topics are popular in each Asian country.

The empirical study provides some implications marketing researchers in Asia. Firstly, Asian academia needs journals that concentrate on marketing research, in order to act as a medium for Asian researchers to access other researchers' findings easily and to provide a platform for those researchers to communicate with each other. Unfortunately, most Asian countries do not own their marketing journals, which has become a hurdle for the development of a research network in Asia. Without a marketing journal, marketing associations cannot attract active researchers, nor encourage them to work on more Asian market-related research. The establishment of international marketing journals in Asia can be a springboard for Asian researchers and marketing associations to enrich more relevant research about Asian markets and provide a unique and more lively exchange of knowledge for Asian researchers. Even though marketing associations, in East Asian countries such as China, Japan, and South Korea, own their marketing journals, most of the marketing associations were local journals that publish research manuscripts written in their local language. Therefore, research interactions among researchers in those countries had not been active until the birth of AMJ and ICAMA. In line with that, AMJ, and ICAMA, the international conference managed by major Asian marketing associations for Asian researchers, are expected to make a significant contribution to the network of Asian scholars.

Secondly, it is also significantly helpful for Asian marketing journals to be indexed by international bibliographic databases for academic journal articles, such as SCOPUS, SCI, SSCI, and so on. However, few Asian marketing journals have been indexed by the globally-recognized citation databases. Since 2000, countries in Asia started to develop their own research citation databases in order to improve university rankings for their local universities, or to provide their students information on universities for university selections, as shown in 〈Table 3〉 below.

Even though more and more Asian countries have organized their local research database and their indexes these days, such local research databases are not effective for Asian marketing journals in exposing them to researchers in other Asian countries.

Lastly, and most importantly, the success of 
〈Table 3〉 Citation Databases in Asia

\begin{tabular}{|c|l|l|l|}
\hline Nationality & \multicolumn{1}{|c|}{ Citation Database } & \multicolumn{1}{|c|}{ Organization } & \multicolumn{1}{c|}{ Website } \\
\hline Australia & DCI (Data Citation Index) & Australian National Data Service & http://ands.org.au \\
\hline China & $\begin{array}{l}\text { Chinese Science Citation } \\
\text { Index }\end{array}$ & $\begin{array}{l}\text { the Natural Sciences Foundation } \\
\text { of China }\end{array}$ & http://cssci.nju.edu.cn \\
\hline Japan & $\begin{array}{l}\text { CiNii (Scholarly and } \\
\text { Academic Information } \\
\text { Navigator) }\end{array}$ & $\begin{array}{l}\text { the National Institute of } \\
\text { Informatic }\end{array}$ & http://cinnii.ac.jp/en \\
\hline India & ICI (Indian Citation Index) & The Knowledge Foundation & http://www.indiancitationindex.com \\
\hline Russia & $\begin{array}{l}\text { MCI (Malaysian Citation } \\
\text { Index) }\end{array}$ & $\begin{array}{l}\text { Russian Science Citation } \\
\text { Index } \\
\text { (The Ministry of Education) }\end{array}$ & hussian Science Foundation \\
\hline Philippines & $\begin{array}{l}\text { PJCI (The Philippine } \\
\text { Journal Citation Index } \\
\text { Database) }\end{array}$ & $\begin{array}{l}\text { the Journal Accreditation Service } \\
\text { of the Commission on Higher } \\
\text { Education of the Philippines }\end{array}$ & http://pjcid.adnu.edu.ph \\
\hline South Korea & $\begin{array}{l}\text { KCI (Korea Citation } \\
\text { Index) }\end{array}$ & $\begin{array}{l}\text { National Research Foundation of } \\
\text { Korea }\end{array}$ & http://www.kci.go.kr \\
\hline Taiwan & $\begin{array}{l}\text { TSSCI (Taiwan Citation } \\
\text { Index) }\end{array}$ & Taiwan National Science Council \\
\hline http://ssrc.sinica.edu.tw \\
\hline
\end{tabular}

Asian journals depends on how they differentiate their roles and research directions against other well established international journals. Asian marketing journals and conferences need to find a differentiated position against Western journals and conferences. Finding a differentiated identity is the key to the successful settlement of Asian marketing journals. If Asian journals follow the research directions that well-known Western journals have been pursuing, they cannot make a contribution at all in the marketing literature. Researchers have not much reason to submit their high quality papers to Asian marketing journals, given that there are plenty of prestigious Western journals, if those journals prefer the same research topics. Asian journals need to lead Asian academia to deal with more Asian market-related research topics, for instance better understanding cultural differences among Asian consumers and the affect those differences have on Asian consumers' preference heterogeneity and homogeneity, globalization or localization strategy for Asian companies in Asian markets, the difference between aging markets in East Asia and emerging markets in ASEAN countries, and so on.

〈Received February 5. 2016〉 $\langle$ Accepted February 21. 2016〉 


\section{Appendix A: Major Universities in Asia}

\begin{tabular}{|c|c|c|c|}
\hline Country & University & Accrediation & Websites \\
\hline Australia & Australian National University & - & programsandcourses.anu.edu.au/ \\
\hline Australia & La Trobe University & - & latrobe.edu.au/ \\
\hline Australia & Macquarie University & AACSB & mgsm.edu.au/ \\
\hline Australia & Monash University & Triple & business.monash.edu/ \\
\hline Australia & Queensland University Of Technology & Triple & qut.edu.au/ \\
\hline Australia & The University Of Adelaide & AACSB & business.adelaide.edu.au/ \\
\hline Australia & The University Of Western Australia & AACSB / EQUIS & business.uwa.edu.au/ \\
\hline Australia & University Of Melbourne & AACSB / EQUIS & mbs.edu/home \\
\hline Australia & University Of New South Wales & AACSB / EQUIS & business.unsw.edu.au/ \\
\hline Australia & University Of Queensland & AACSB / EQUIS & uq.edu.au/ \\
\hline Australia & University Of Sydney & AACSB / EQUIS & http://sydney.edu.au/ \\
\hline China & China Europe International Business School & AACSB / EQUIS & en.ceibs.edu/ \\
\hline China & Fudan University & AACSB / EQUIS & fdsm.fudan.edu.cn/En/ \\
\hline China & $\begin{array}{l}\text { Lingnan (University) College, Sun Yat-Sen } \\
\text { University }\end{array}$ & Triple & lingnan.sysu.edu.cn/en/ \\
\hline China & Nanjing University & AACSB & nju.edu.cn/english/ \\
\hline China & Peking University, BIMBA & AACSB / EQUIS & en.bimba.edu.cn/ \\
\hline China & Peking University, Guanghua MBA & AACSB / EQUIS & gsm.pku.edu.cn/mba/en/ \\
\hline China & Renmin University Of China & AACSB / EQUIS & mbaen.rbs.org.cn/ \\
\hline China & Shanghai Jiao Tong University, Antai MBA & Triple & mba.sjtu.edu.cn/en/ \\
\hline China & Sun Yat-Sen University & Triple & sysu.edu.cn/ \\
\hline China & Tsinghua University & AACSB & mba.sem.tsinghua.edu.cn/mbaen/ \\
\hline China & $\begin{array}{l}\text { University Of Science And Technology Of } \\
\text { China }\end{array}$ & $\mathrm{AACSB} / \mathrm{AMBA}$ & sem.ustb.edu.cn/ \\
\hline China & Zhejiang University & Triple & zju.edu.cn/english/ \\
\hline Hong Kong & City University Of Hong Kong & EQUIS & cb.cityu.edu.hk/ \\
\hline Hong Kong & Hong Kong Baptist University & Triple & buhkbu.edu.hk/eng/main/ \\
\hline Hong Kong & $\begin{array}{l}\text { Hong Kong University Of Science And } \\
\text { Technology }\end{array}$ & $\mathrm{AACSB}$ & mba.ust.hk/ \\
\hline Hong Kong & Lingnan University & $\mathrm{AACSB}$ & ln.edu.hk/ \\
\hline Hong Kong & The Chinese University Of Hong Kong & AACSB & mba.cuhk.edu.hk/ \\
\hline Hong Kong & The Hong Kong Polytechnic University & AACSB / EQUIS & polyu.edu.hk/fb/ \\
\hline Hong Kong & The University Of Hong Kong & AACSB / EQUIS & mba.hku.hk/ \\
\hline India & Great Lakes Institute Of Management & - & greatlakes.edu.in/ \\
\hline India & Indian Institute Of Management, Ahmedabad & EQUIS & iimahd.ernet.in/ \\
\hline India & Indian Institute Of Management, Bangalore & EQUIS & iimb.ernet.in/ \\
\hline India & Indian Institute Of Management, Calcutta & AACSB / AMBA & iimcal.ac.in/ \\
\hline
\end{tabular}


(continue)

\begin{tabular}{|c|c|c|c|}
\hline Country & University & Accrediation & Websites \\
\hline India & Indian Institute Of Management, Kozhikode & AMBA & iimk.ac.in/ \\
\hline India & Indian Institute Of Management, Lucknow & AMBA & iiml.ac.in/ \\
\hline India & Indian School Of Business & AACSB & isb.edu/ \\
\hline India & International Management Institute, Delhi & AMBA & imi.edu/ \\
\hline India & Management Development Institute & AMBA & mdi.ac.in/login.html \\
\hline India & $\begin{array}{l}\text { Sp Jain Institute Of Management And } \\
\text { Research }\end{array}$ & AMBA & spjimr.org/ \\
\hline India & SVKM’s NMIMS, Bangalore & AMBA & nmimsbengaluru.org/ \\
\hline India & T. A. Pai Management Institute & AACSB & tapmi.edu.in/ \\
\hline Indonesia & Airlangga University, Faculty Of Economy & - & unair.ac.id/ \\
\hline Indonesia & Institut Teknologi Bandung & - & sbm.itb.ac.id/mba \\
\hline Indonesia & IPMI International Business School & - & ipmi.ac.id/index/en \\
\hline Indonesia & Prasetiya Mulya Business School & - & pmbs.ac.id/ \\
\hline Indonesia & Universitas Gadjah Mada & AACSB & mm.feb.ugm.ac.id/ \\
\hline Indonesia & University Of Indonesia Faculty Of Economics & - & feb.ui.ac.id/ \\
\hline Japan & Keio University & AACSB / EQUIS & kbs.keio.ac.jp/en/ \\
\hline Japan & Kyoto Universtiy & - & gsm.kyoto-u.ac.jp/en/ \\
\hline Japan & Mcgill University Japan & - & mcgillmbajapan.com/ \\
\hline Japan & $\begin{array}{l}\text { Meiji University, } \\
\text { School Of Business Administration }\end{array}$ & - & $\begin{array}{l}\text { meiji.ac.jp/cip/english/undergraduate } \\
\text { /business/ }\end{array}$ \\
\hline Japan & Meiji University, School Of Commerce & - & $\begin{array}{l}\text { meiji.ac.jp/cip/english/undergraduate } \\
\text { /commerce/ }\end{array}$ \\
\hline Japan & Meiji University, School Of Global Business & - & $\begin{array}{l}\text { meiji.ac.jp/cip/english/graduate } \\
\text { /business/ }\end{array}$ \\
\hline Japan & $\begin{array}{l}\text { Nagoya University Of Commerce And } \\
\text { Business }\end{array}$ & $\mathrm{AACSB} / \mathrm{AMBA}$ & nucba.ac.jp/en/ \\
\hline Japan & Temple University, Japan Campus & - & tuj.ac.jp/index.html \\
\hline Japan & Waseda University & - & waseda.jp/fcom/wbs/en \\
\hline Malaysia & Universiti Utara Malaysia & AMBA & oyagsb.uum.edu.my/ \\
\hline Malaysia & Putra Business School & AACSB & putrabusinessschool.edu.my/ \\
\hline Malaysia & Universiti Kebangsaan Malaysia & - & ukm.my/gsbukm/ \\
\hline Malaysia & Universiti Malaya & AMBA & um.edu.my/ \\
\hline Malaysia & Universiti Putra Malaysia & AACSB & putrabusinessschool.edu.my/ \\
\hline Malaysia & Universiti Sains Malaysia & - & gsb.usm.my/v2/ \\
\hline Mongolia & Ider University & - & ider.edu.mn/ \\
\hline Mongolia & Institute Of Finance And Economics & - & ife.edu.mn/ \\
\hline Mongolia & Mongolia International University & - & miu.edu.mn/miu/cbah.php \\
\hline Mongolia & Mongolian National University & - & mnu.edu.mn/ \\
\hline Mongolia & $\begin{array}{l}\text { Mongolian University Of Science And } \\
\text { Technology }\end{array}$ & - & must.edu.mn/mn/ \\
\hline
\end{tabular}


(continue)

\begin{tabular}{|c|c|c|c|}
\hline Country & University & Accrediation & Websites \\
\hline Mongolia & National University Of Mongolia & - & num.edu.mn/en/ \\
\hline Mongolia & Orkhon University & - & orkhon.edu.mn/ \\
\hline Mongolia & Ulaanbaatar University & - & ulaanbaatar.edu.mn/ \\
\hline New Zealand & Auckland University Of Technology & AACSB & aut.ac.nz/study-at-aut/ \\
\hline New Zealand & Massey University & AACSB / AMBA & business.massey.ac.nz/ \\
\hline New Zealand & The University Of Auckland & Triple & mba.auckland.ac.nz/ \\
\hline New Zealand & University Of Canterbury & $\mathrm{AACSB} / \mathrm{AMBA}$ & mba.canterbury.ac.nz/ \\
\hline New Zealand & University Of Otago & AACSB / EQUIS & otagomba.com/ \\
\hline New Zealand & University Of Waikato & Triple & waikato.ac.nz/ \\
\hline New Zealand & Victoria University Of Wellington & Triple & victoria.ac.nz/som/study/ \\
\hline Russia & $\begin{array}{l}\text { International Management Institute } \\
\text { St. Petersburg }\end{array}$ & AMBA & imisp.ru/ \\
\hline Russia & Lomonosov Moscow State University & - & en.mgubs.ru/ \\
\hline Russia & $\begin{array}{l}\text { MBA Higher School, Kazan Federal } \\
\text { University }\end{array}$ & AMBA & mba-kazan.ru/ \\
\hline Russia & $\begin{array}{l}\text { MIRBIS Moscow International Higher } \\
\text { Business School }\end{array}$ & AMBA & mirbis.ru/ \\
\hline Russia & $\begin{array}{l}\text { Moscow School Of Social And } \\
\text { Economic Sciences }\end{array}$ & AMBA & kingston.ane.ru/ \\
\hline Russia & $\begin{array}{l}\text { Plekhanov Business School Integral, } \\
\text { Plekhanov Russian University Of Economics }\end{array}$ & AMBA & rea.ru/ \\
\hline Russia & Saint Petersburg University & EQUIS / AMBA & gsom.spbu.ru/en/ \\
\hline Russia & $\begin{array}{l}\text { State University Of Management, } \\
\text { School Of Business }\end{array}$ & AMBA & hbs-guu.ru/ \\
\hline Russia & Synergy Business School & - & synergy.ru/ \\
\hline Russia & $\begin{array}{l}\text { The Russian Presidential Academy of } \\
\text { National Economy And Public } \\
\text { Administration }\end{array}$ & AMBA & emba.rane.ru/en \\
\hline Singapore & Insead Singapore & Triple & insead.edu/home/ \\
\hline Singapore & Nanyang Business School & AACSB / EQUIS & nbs.ntu.edu.sg/ \\
\hline Singapore & National University of Singapore & AACSB / EQUIS & mba.nus.edu/ \\
\hline Singapore & Singapore Institute of Management & - & sim.edu.sg/ \\
\hline Singapore & Singapore Management University & AACSB / EQUIS & business.smu.edu.sg/ \\
\hline Korea & Chung Ang University & - & biz.cau.ac.kr/ \\
\hline Korea & Dongguk University & AACSB & mba.dongguk.edu/ \\
\hline Korea & Ewha Womans University & AACSB & biz.ewha.ac.kr/ \\
\hline Korea & Hankuk University Of Foreign Studies & - & bizeng.hufs.ac.kr/ \\
\hline Korea & Hanyang University & AACSB & biz.hanyang.ac.kr/ \\
\hline Korea & Konkuk University & AACSB & mba.konkuk.ac.kr/ \\
\hline
\end{tabular}


(continue)

\begin{tabular}{|c|c|c|c|}
\hline Country & University & Accrediation & Websites \\
\hline Korea & Korea University & AACSB / EQUIS & bizl.korea.ac.kr/en/ \\
\hline Korea & Kyung Hee University & - & ekbiz.khu.ac.kr/ \\
\hline Korea & Seoul National University & AACSB & gsb.snu.ac.kr/en/ \\
\hline Korea & Sogang University & AACSB & sbs.ac.kr/en/ \\
\hline Korea & Sungkyunkwan University & AACSB & gsb.skku.edu/en/ \\
\hline Korea & Yonsei University & AACSB / EQUIS & mba.yonsei.ac.kr/ \\
\hline Taiwan & Feng Chia University & AACSB & en.fcu.edu.tw/wSite/mp?mp =3 \\
\hline Taiwan & Fu Jen Catholic University & AACSB & management.fju.edu.tw/ \\
\hline Taiwan & National Central University & AACSB & mgt.ncu.edu.tw/index/main.php \\
\hline Taiwan & National Cheng Kung University & AACSB & imba.ncku.edu.tw/main.php \\
\hline Taiwan & National Chengchi University & AACSB / EQUIS & imba.nccu.edu.tw/ \\
\hline Taiwan & National Chiao Tung University & - & com.nctu.edu.tw/ \\
\hline Taiwan & National Sun Yat-Sen University & AACSB & mbaen.bssysu.com/ \\
\hline Taiwan & National Taiwan University & AACSB & management.ntu.edu.tw/en/GMBA \\
\hline Taiwan & $\begin{array}{l}\text { National Taiwan University } \\
\text { of Science And Technology }\end{array}$ & AACSB & management.ntust.edu.tw/ \\
\hline Taiwan & National Tsing Hua University & - & nthu.edu.tw/ \\
\hline Thailand & Assumption University & - & graduate.au.edu/ \\
\hline Thailand & Chulalongkorn University & AACSB / EQUIS & mbachula.info/mba-english-program \\
\hline Thailand & $\begin{array}{l}\text { National Institute Of Development } \\
\text { Administration }\end{array}$ & AACSB & mba.nida.ac.th/en/ \\
\hline Thailand & Stamford International University & - & stamford.edu/ \\
\hline Thailand & Thammasat Business School & - & tbs.tu.ac.th/14/en/ \\
\hline The Philippines & Asian Institute Of Management & - & aim.edu/ \\
\hline The Philippines & Ateneo De Manila University & - & gsb.ateneo.edu/ \\
\hline The Philippines & De La Salle University & - & dlsu.edu.ph/academics/ \\
\hline The Philippines & $\begin{array}{l}\text { University Of San Carlos } \\
\text { School Of Business and Economics }\end{array}$ & - & usc.edu.ph/sbe/ \\
\hline The Philippines & $\begin{array}{l}\text { University Of Santo Tomas } \\
\text { Ust Graduate School }\end{array}$ & - & ust.edu.ph/ \\
\hline The Philippines & $\begin{array}{l}\text { University Of The Philippines, } \\
\text { Cesar E. A. Virata School Of Business }\end{array}$ & - & upd.edu.ph/ cba/ \\
\hline Vietnam & $\begin{array}{l}\text { Centre Franco-Vietnamien De Formation } \\
\text { À La Gestion }\end{array}$ & - & cfvg.org/ \\
\hline Vietnam & FPT School Of Business, FPT University & - & fsb.edu.vn/ \\
\hline Vietnam & Ho Chi Minh City University of Technology & - & mba-mci.edu.vn/en/ \\
\hline Vietnam & RMIT University Vietnam & - & rmit.edu.vn/ \\
\hline Vietnam & University of Econmics, HCMC & - & ueh.edu.vn/ \\
\hline Vietnam & Vietnam National University & - & hsb.edu.vn/ \\
\hline
\end{tabular}

